\title{
Discussion
}

\section{UK sustainable drainage systems: past, present and future}

By Richard Ashley, Louise Walker, Brian D'Arcy, Steve Wilson, Sue Illman, Paul Shaffer, Bridget Woods Ballard and Phil Chatfield (August 2015)

\section{Contribution by David Smith}

Ashely et al. (2015) look at the cost of sustainable drainage systems (Suds) in terms of cost-benefit, but I think cost should be included in the definition of sustainability. This would drive inexpensive solutions, which would be more acceptable in the first place.

Addressing problems at source is better than treating the symptoms. The Environment Agency has failed to raise the profile of the major origins of significant problems and the public is still unaware of them. Examples include the washing machine in the garage and tipping waste oil into the road gulley.

In the present adverse climate in England, perhaps we should welcome experimental solutions. Swales and infiltration systems are preferable to local ponds, which collect debris, become polluted and children play in them. Major Suds like flood meadows and balancing reservoirs are likely to be better cost-benefit, particularly in the context of retrofits.

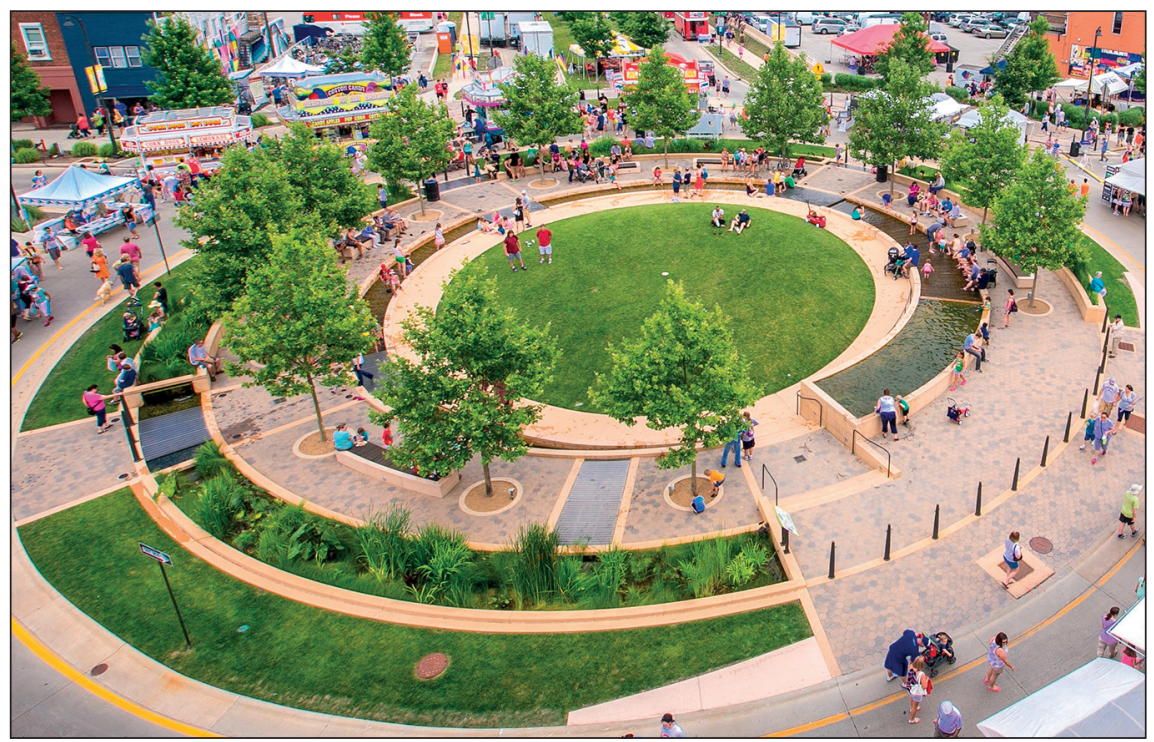

All forms of water present opportunities for Suds schemes, such as at this multifunctional roundabout in the USA

\section{Authors' reply}

Sustainability concepts are revisited in Ciria's recently revised Suds manual (Woods-Ballard et al., 2015). Though restated in terms of the government's core principles, they are not otherwise prescribed in the guidance. In some instances, fewer or no Suds may prove to be more sustainable as this depends on the context of use. Traditional piped drainage may be considered inexpensive in certain instances, but only where the global impact on climate, resource use and missed opportunities are ignored, as pointed out in Ciria's guidance on benefits of Suds (Horton et al., 2015).

We entirely agree with the need to address issues at source rather than deal with symptoms. This is why the new Suds manual starts from an opportunity-centred approach rather than a problem-centred one. All forms of water, wherever they first appear, present opportunities. With the pace of climate and other changes, much more strenuous efforts are required to engage everyone in a better understanding of the water cycle and how we can manage it better, especially for using Suds.

Innovation will always require experimental 'solutions', although Suds are now way beyond the experimental stage as demonstrated by numerous examples on Ciria's Susdrain website (Ciria, 2015). Regarding retrofit, as stated in the new Suds manual and earlier retrofit guidance (Digman et al., 2012) there is a palette of Suds measures and these cannot be predefined for applicability in any given situation. It is the context and specific application that defines the suitability of a given Suds option and its role as part of a train of measures. For example, the award-winning Suds retrofit scheme in Llanelli, west Wales (Ellis et al., 2016) required a range of small and microscale installations close to source and on the surface. Pre-exclusion of Suds options without considering the context is not recommended.

\section{References}

Ashley R, Walker L, D'Arcy B et al. (2015) UK sustainable drainage systems: past, present and future. Proceedings of the Institution of Civil Engineers - Civil Engineering 168(3): 125-130, http://dx.doi.org/10.1680/cien.15.00011 Ciria (2015). Susdrain. Construction Industry Research and Information Association, London, UK. See http://www.susdrain.org/ (accessed 30/11/2015)

Digman C, Ashley R, Balmforth D et al. (2012) Retrofitting to Manage Surface Water. Construction Industry Research and Information Association, London, UK, C713. See http:// www.susdrain.org/resources/ciria-guidance.html (accessed 30/11/2015).

Ellis C, Cripps R, Russ M and Broom S (2016) Transforming water management in Llanelli, UK. Proceedings of the Institution of Civil Engineers - Civil Engineering 169(1): 25-33, http://dx.doi org/10.1680/jcien.15.00027.

Horton B, Digman C, Ashley R and Gill E (2015) BeST (Benefits of SuDS Tool) - Technical Guidance. Construction Industry Research and Information Association, London, UK, CIRIA W045c RP993. See http://www.susdrain.org/ resources/best.html (accessed 30/11/2015).

Woods-Ballard B, Wilson S, Udale-Clarke H et al. (2015) The SuDS Manual. Construction Industry Research and Information Association, London, UK, C753. See http://www.susdrain. org/resources/SuDS_Manual.html (accessed 30/11/2015). 